\title{
THERMODYNAMIC ANALYSIS OF CaO - SiO2 - Al2O3 - MgO SLAG SYSTEM
}

\author{
${ }^{1}$ Michal SNIEGOŇ, ${ }^{1}$ Markéta TKADLEČKOVÁ, ${ }^{2}$ Tomáš HUCZALA, ${ }^{1}$ Karel MICHALEK, \\ ${ }^{1}$ Lucie CHUDOBOVÁ, ${ }^{1}$ Michaela STROUHALOVÁ, ${ }^{1}$ Josef WALEK, ${ }^{3}$ Jacek PIEPRZYCA \\ ${ }^{1}$ VSB - Technical University of Ostrava, Ostrava, Czech Republic, EU, michal.sniegon@vsb.cz, \\ marketa.tkadleckova@vsb.cz, karel.michalek@vsb.cz, lucie.chudobova@vsb.cz, \\ michaela.strouhalova@vsb.cz, josef.walek@vsb.cz, \\ ${ }^{2}$ Trinnecké železárny a.s., Tomas.Huczala@trz.cz, \\ 3Politechnika Ślaska, Gliwice, Poland, EU, Jacek.Pieprzyca@polsl.pl
}

\section{https://doi.org/10.37904/metal.2021.4084}

\begin{abstract}
The paper deals with the possibility of thermodynamic analysis of $\mathrm{CaO}-\mathrm{SiO} 2-\mathrm{Al} 2 \mathrm{O} 3-\mathrm{MgO}$ slag system for optimizing of steel desulphurization in a ladle. From the point of view of reducing the sulphur content in steel, the chemical composition of the slag plays a crucial role which affects a critical thermodynamic parameter of the slag, such as the liquidus temperature of the slag, the amount of solid phases in slag at range of refining temperatures, respectively the effective viscosity of slag and $\mathrm{CaO}$ saturation in slag. The critical parameters were analyzed in dependence on the content of $\mathrm{MgO}$ in slag. The analysis was performed in FactSage 7.2 software. A quaternary graphs of the slag system $\mathrm{CaO}-\mathrm{SiO} 2-\mathrm{Al} 2 \mathrm{O} 3-\mathrm{MgO}$ were created with a constant $\mathrm{MgO}$ content of $0 \mathrm{wt} . \%, 5 \mathrm{wt} \%, 10 \mathrm{wt} . \%$ and $15 \mathrm{wt} . \%$. The results of thermodynamic calculations confirm that the content of $\mathrm{MgO}$ among $5 \%$ and $10 \%$ will have a positive effect on expanding the area of the lowest liquidus temperature and therefore better viscosity of slag. On the other hand, the content of $\mathrm{MgO}$ above $8 \%$ led to higher content of solid phases which affected negatively the viscosity.
\end{abstract}

Keywords: FactSage, properties of ladle furnace slag, furnace ladle slag, basicity of ladle furnace slag, temperature of liquid slag

\section{INTRODUCTION}

Improving the competitiveness of steel companies is associated with sustainable, satisfactory steel production. Ladle metallurgy is the last place where you can further adjust the chemical composition of steel, partially remove inclusions from steel and reduce unwanted elements in steel, such as sulphur. Under operating conditions, it is often very difficult to perform a series of targeted experiments to verify the effectiveness of the selected metallurgical process to reduce sulphur content, so simulation software is used to help optimize production processes [1-4].

One of the helpful software that can be used in evaluating the course of metallurgical processes is FactSage. FactSage is a thermodynamic/thermochemical software which is based on thermodynamic calculations of energy functions from empirically obtained values of thermo-physical properties of materials (heat capacities, enthalpies, phase transformation temperatures, etc.), both steels and slag, determines eg. phase or chemical transformations during metallurgical processes [5-7].

One of the main parameters that affects desulphurization is the saturation of $\mathrm{CaO}$ in the slag. The lime saturation index is an important parameter that is determined as the ratio of the actual $\mathrm{CaO}$ content to the $\mathrm{CaO}$ content of the saturated slag lime. The authors of the article [8] claim that saturated calcium slags have the highest desulphurization effectivity. Insufficient lime saturation in the ladle slag leads to a reduction in the desulphurization effect. Higher $\mathrm{MgO}$ content in the slag affects the desulphurization processes. The authors 
found that increasing the content of $\mathrm{MgO}$ in the slag leads to saturation of the $\mathrm{MgO}$ in the slag, resulting the extention of life of the refractory lining, but on the contrary deteriorating the desulphurization reaction rate steel. Therefore, it is important to find the optimal content of $\mathrm{MgO}$ in the slag, so that the $\mathrm{MgO}$ in the slag is saturated and positively affects the reaction rate of desulphurization. Great influence on the reduction of sulphur content in the steel has a significant influence of the solids and liquid phase. Effective viscosity means a lower solids content (lower viscosity) and ensures faster solubility of $\mathrm{CaO}$ in the slag. To keep the liquid phase of the slag, it is important that the $\mathrm{CaO}$ is saturated [8-11].

The main goal of the paper is to analyze the critical parameters that affect metallurgical processes during steel desulphurization. The main parameters that affect desulphurization are: $\mathrm{CaO}$ saturation in ladle slag, dependence of slag liquidus temperature on $\mathrm{MgO}$ content in slag, slag viscosity and $\mathrm{MgO}$ content on the fraction of the excluded phase.

\section{CHARACTERISTICS OF LADLE SLAG CaO $-\mathrm{SiO}_{2}-\mathrm{Al}_{2} \mathrm{O}_{3}-\mathrm{MgO}$}

The data set used for the experimental study itself represents data with the appropriate chemical composition of the slags of 66 specific melts. Slags of steel grades with a similar chemical composition were selected. In all cases, it was aluminum-tempered steel. Tapping from the primary steelmaking, in this case the oxygen converter, was followed by out-of-furnace refining of the steel. Samples for determining the chemical composition of the slag were taken at the end of the processing of the steel in a ladle furnace. Ranges of chemical composition of ladle slags are given in Table 1.

Table 1 Ranges of chemical composition of the examined ladle slag

\begin{tabular}{|c|c|c|c|c|c|c|c|c|c|c|}
\hline \multicolumn{10}{|c|}{ Chemical composition of ladle slag (wt.\%) } \\
\hline $\mathrm{Fe}_{\text {total }}$ & $\mathrm{MnO}$ & $\mathrm{SiO}_{2}$ & $\mathrm{Al}_{2} \mathrm{O}_{3}$ & $\mathrm{CaO}$ & $\mathrm{MgO}$ & $\mathrm{S}$ & $\mathrm{P}_{2} \mathrm{O}_{5}$ & $\mathrm{Cr}_{2} \mathrm{O}_{3}$ & $\mathrm{TiO}_{2}$ & $\mathrm{CaF}_{2}$ \\
\hline $0.2-0.8$ & $0.04-0.60$ & $8-21$ & $19-31$ & $40-60$ & $7-20$ & $0.4-1$ & $0.01-0.05$ & $0-0.2$ & $0.20-0.30$ & $0-2$ \\
\hline
\end{tabular}

As it is evident from Table 1 that $\mathrm{CaO}$ is present in the largest amount of the main oxides. The high occurrence of $\mathrm{CaO}$ in the slag indicates the slag regime, which is designed for desulphurization of steel. We know from theory that for the desulphurization of steel it is necessary to reduce the FeO content in the slag. However, experience shows that not only $\mathrm{FeO}$ in slag has an effect on the desulphurization of steel, but the content of $\mathrm{MnO}$ and $\mathrm{MgO}$ in slag also play an important role during metallurgical processes. 66 combinations of the chemical composition of ladle slags were subsequently used to calculate and compile quaternary diagrams of the properties of ladle slags in SW FactSage.

\section{COMPILATION OF QUATERNARY DIAGRAMS OF LADLES SLAGS AL2O3-SIO2-CAO-MGO IN SW FACTSAGE AND CALCULATION OF SLAG PROPERTIES}

Quaternary diagrams were compiled for the slag system $\mathrm{CaO}$ - $\mathrm{SiO} 2$ - $\mathrm{Al} 2 \mathrm{O} 3$ - $\mathrm{MgO}$ with a constant $\mathrm{MgO}$ content of $0 \mathrm{wt} . \%, 5 \mathrm{wt} . \%, 10 \mathrm{wt} . \%$ and $15 \mathrm{wt} . \%$. The aim of the calculations was to determine the extent to which $\mathrm{MgO}$ affects the resulting properties of the slag. Practice shows that as the MgO content in the slag increases, the area of thermal liquidity of the slag, the amount of solid phase precipitated in the slag at steel processing temperatures and the saturation of the $\mathrm{CaO}$ slag also change dramatically.

\subsection{Determination of slag liquidus temperature}

An important parameter for slag optimization is knowledge of its liquidus temperature. The liquidus temperature affects the rate and kinetics of the chemical reaction between the slag and the metal $[12,13,18]$. The liquidus temperature of ladle slags was determined for the chemical composition with a $\mathrm{MgO}$ content in the range of 0 to $15 \%$ by weight and at processing temperatures in the range from 1,450 to $1,650{ }^{\circ} \mathrm{C}$. A comparison of 
quaternary diagrams of slags with a constant $\mathrm{MgO}$ content of $0,5,10$ and $15 \mathrm{wt} . \%$ is shown in Figure 1. The colors of the slag liquidus temperature scale to the right of the diagram correspond to the colors of the isotherms in the diagram. The isotherms in the diagram then define the area of the slag melting temperature area for individual ratios of the contents of the main components of ladle slag. The area defined in the diagram by the pink curve is therefore considered to be the place with the lowest liquidus temperature of $1,450^{\circ} \mathrm{C}$. In the red area, the liquidus temperatures reach $1,650^{\circ} \mathrm{C}$. During the desulphurization of steel in secondary metallurgy, metallurgical reactions take place in the diagram marked with an orange oval area. The diagram also intersects lines marking areas with different slag basicity.

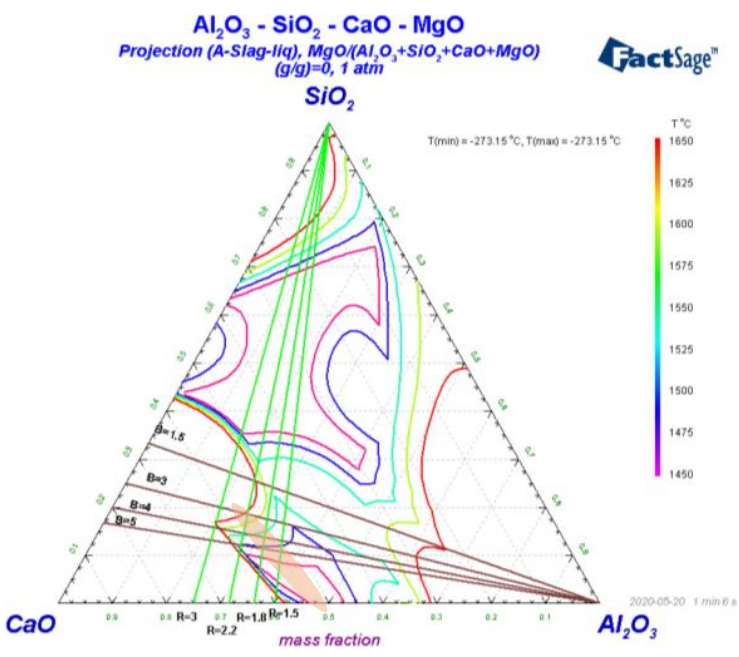

a) $0 \% \mathrm{MgO}$

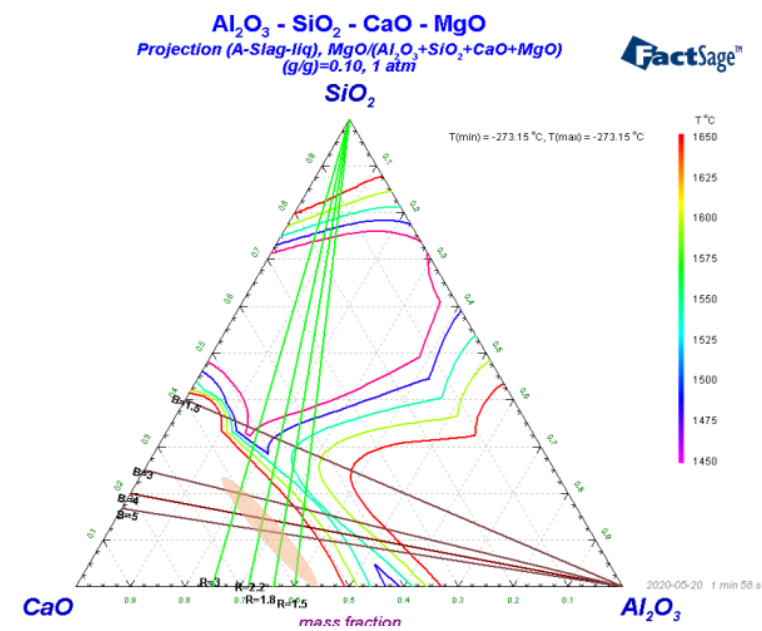

c) $10 \% \mathrm{MgO}$

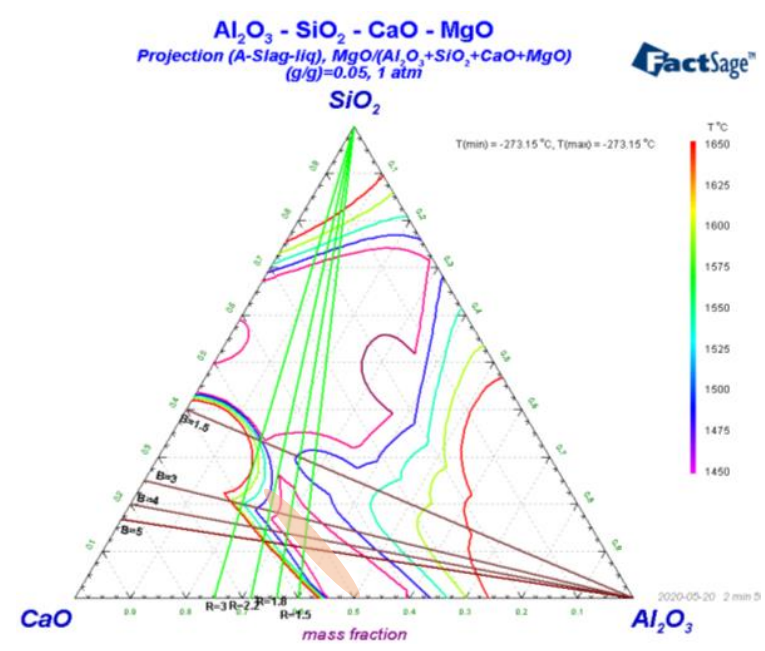

b) $5 \% \mathrm{MgO}$

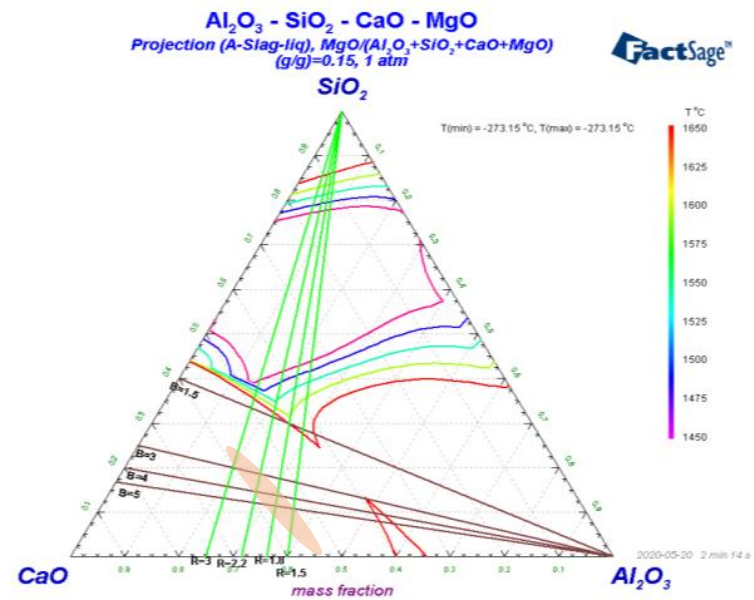

d) $15 \% \mathrm{MgO}$

Figure 1 Comparison of quaternary diagrams of slag systems with a) $0 \% \mathrm{MgO}$, b) $5 \% \mathrm{MgO}$, c) $10 \% \mathrm{MgO}$ d) $15 \% \mathrm{MgO}$ and their liquidus temperatures

As can be seen from Figure 1 for 0 wt.\% $\mathrm{MgO}$ in the slag, all liquidus temperature ranges (isolines) are in the orange range, in the isolines have a narrow liquidus temperature range. When the $\mathrm{MgO}$ content in the slag is increased to $5 \%$, the pink temperature range expands. Increasing the $\mathrm{MgO}$ to $10 \%$ results in the orange region suddenly reaching the red isothermal region (liquidus temperature $1,650{ }^{\circ} \mathrm{C}$ ), which negatively affects the kinetics of the desulphurization process by increasing the viscosity. In addition, only one pink isothermal region is shown compared to the diagram with lower MgO contents in the slag. Furthermore, it is evident that when 
the $\mathrm{MgO}$ content in the slag is increased to $15 \%$, there are not very positive effects during the desulphurization of the steel due to the increase in the liquidus temperature. Therefore, the optimal $\mathrm{MgO}$ content in the slag, in the range of 5 to $10 \mathrm{wt} . \% \mathrm{MgO}$, was determined using FactSage software. As a result, it can be stated that increasing the amount of $\mathrm{MgO}$ in the slag to $10 \%$ will expand the area of liquid slag. By adding $\mathrm{MgO}$ above $10 \%$, on the other hand, the liquid temperature of the slag increases and thus its viscosity deteriorates and the kinetics of the processes at the slag-metal interface are slowed down.

\subsection{Determination of slag viscosity}

The viscosity was evaluated depending on the $\mathrm{MgO}$ content, the melting point of the slag and the working temperature of the slag during steel processing in the temperature range $1,550-1,600{ }^{\circ} \mathrm{C}$ (based on articles [14-16]). The dynamic viscosity, depending on the temperature and chemical composition of the slag, ranged from 0.018 to $0.194 \mathrm{~Pa} \mathrm{~s}$. Low viscosity values of $0.018 \mathrm{~Pa} s$ were achieved at high slag temperatures (above $1,650{ }^{\circ} \mathrm{C}$ ) and zero $\mathrm{MgO}$ content. As the $\mathrm{MgO}$ content increased to $8 \%$, the slag liquidus temperature range changed positively, which decreased to the processing temperature range (i.e., between 1,550 to $1,600^{\circ} \mathrm{C}$ ), and a lower viscosity value of about 0.6-0.8 Pa s was achieved. However, higher $\mathrm{MgO}$ contents above $8 \%$ led to the exclusion of solid phases, as will be discussed below, which led to an increase in the dynamic viscosity of the slag.

\subsection{Influence of $\mathrm{MgO}$ content on the fraction of the excluded phase}

As mentioned above, the precipitation of the solid phase in the slag negatively affects the viscosity of the slag. Based on articles $[13,17]$ we know, if the slag exceeds $40 \%$ of the solid phase, a highly viscous mass changes from the slag. Figure 2 shows the proportions of precipitated phases which were evaluated at a constant temperature of $1,575^{\circ} \mathrm{C}$ for different contents of $\mathrm{MgO}(0,5,8,10 \%)$. The size of the $\mathrm{CaO}$ secretion area, which is important for the evaluation of $\mathrm{CaO}$ saturation in slag, was evaluated in the diagrams. The site of primary $\mathrm{CaO}$ formation was considered to be the site where $\mathrm{CaO}$ saturation in the slag occurs. Slag-liq is an area with liquid slag. By adding $5 \% \mathrm{MgO}$ to the slag, the area where $\mathrm{CaO}$ oxide is formed narrows and at the same time the area of liquid slag expands. When the $\mathrm{MgO}$ content is increased to $8 \%$, the $\mathrm{CaO}$ area expands again, but at the same time an area with $\mathrm{MgO}$ excretion is already beginning to appear. By further increasing the $\mathrm{MgO}$ content above $10 \%$, the area of liquid slag is already beginning to narrow and the area of excreted $\mathrm{MgO}$ is expanding.

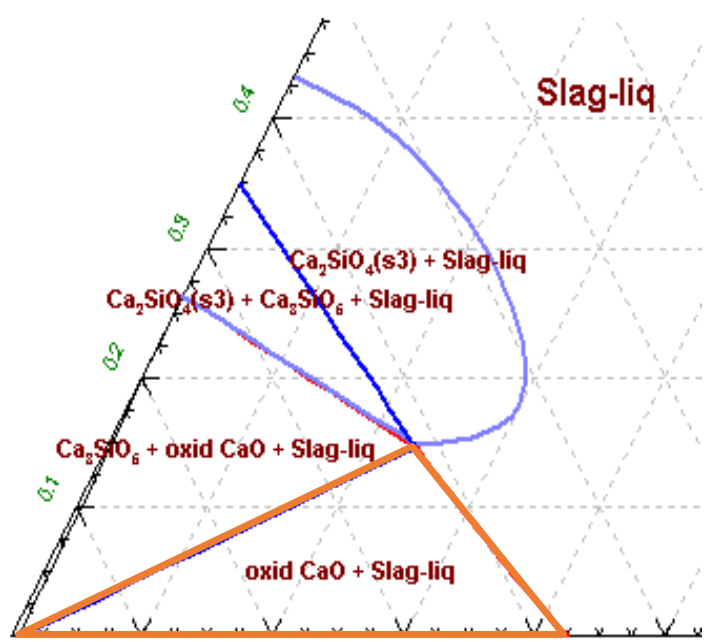

Lower left section of the ternary diagram C-S-A at a temperature of $1,575^{\circ} \mathrm{C}$

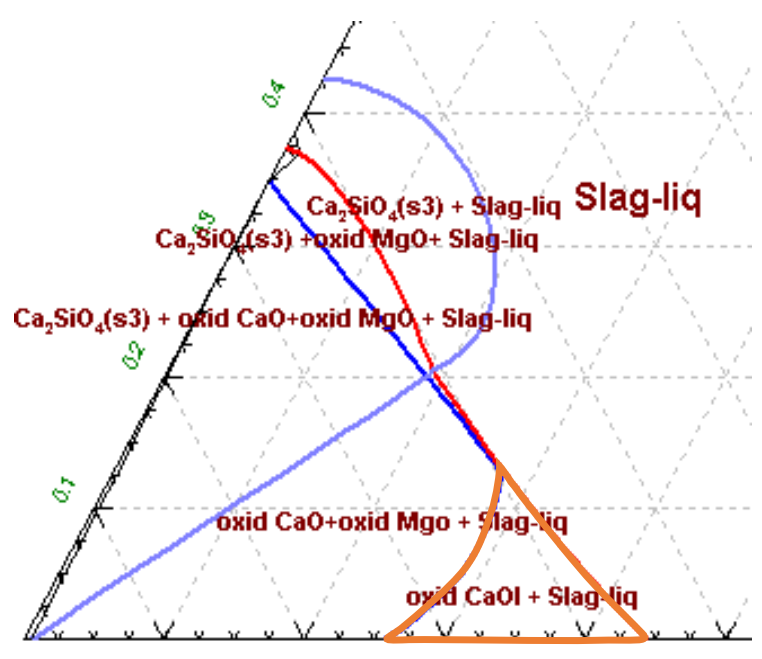

Lower left section of the quaternary diagram C-S$\mathrm{A}-5 \mathrm{M}$ at $1,575^{\circ} \mathrm{C}$ 


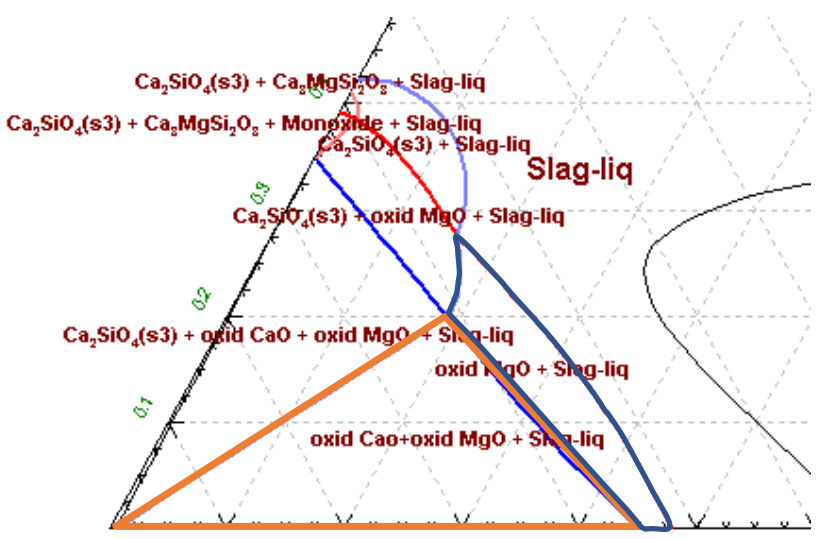

Lower left section of the quaternary diagram $\mathrm{C}-\mathrm{S}-\mathrm{A}-8 \mathrm{M}$ at $1,575^{\circ} \mathrm{C}$

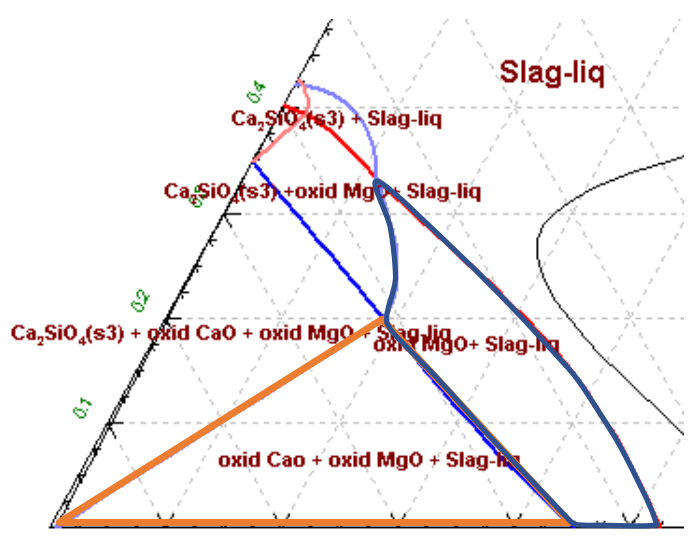

Lower left section of the quaternary diagram $\mathrm{C}-\mathrm{S}$ $\mathrm{A}-10 \mathrm{M}$ at $1,575^{\circ} \mathrm{C}$

Figure 2 Influence of $\mathrm{MgO}$ content on phase formation

The $\mathrm{MgO}$ content positively influences the slag up to 5 wt.\% A to form $\mathrm{CaO}$ oxide in the slag and expand the Slag-liq area. An increase in $\mathrm{MgO}$ to more than $8 \%$ and the formation of $\mathrm{MgO}$ oxide and a mixture of $\mathrm{CaO}$ and $\mathrm{MgO}$ in the orange region have a negative effect.

\section{CONCLUSION}

The article presented the use of thermodynamic software FactSage to find the optimal chemical composition of $\mathrm{CaO}-\mathrm{SiO}_{2}-\mathrm{Al}_{2} \mathrm{O}_{3}-\mathrm{MgO}$ slag in the out-of-furnace desulphurization of steel in a ladle furnace. In practical conditions, the desulphurization efficiency is conditioned by the minimum content of easily reducible oxides (which mainly include $\mathrm{FeO}, \mathrm{MnO}, \mathrm{P}_{2} \mathrm{O}_{5}$ and $\mathrm{Cr}_{2} \mathrm{O}_{3}$ ), the maximum thermodynamic activity of $\mathrm{CaO}$ in the slag (CaO saturation), basicity, processing temperature and slag liquidus temperature and viscosity.

Based on the calculated and constructed quaternary diagrams of the slag system with a variable MgO content from 0 to $15 \%$, the following conclusions were defined:

- $\quad$ The liquidus temperature of ladle slag depends on the $\mathrm{MgO}$ content. At $0 \% \mathrm{MgO}$ in the slag, the area with the lowest slag liquidus temperature around $1,450{ }^{\circ} \mathrm{C}$ is relatively narrow. Increasing the $\mathrm{MgO}$ content between 5 and $10 \%$ will have a positive effect on expanding the area with the lowest liquidus temperature. If the $\mathrm{MgO}$ content is increased to $10 \%$ or more, the liquid slag area will narrow.

- $\quad$ Dynamic viscosity calculations confirmed that the viscosity is affected by the temperature and chemical composition of the slag. As the viscosity of the slag increases, the effective desulphurization of the steel decreases.

- $\quad$ Therefore, in order to achieve effective desulphurization, it is recommended to keep the MgO content in the ladle slag in the range of about $8 \%$ (between 5 and $10 \mathrm{wt} \% \mathrm{MgO}$ ).

\section{ACKNOWLEDGEMENTS}

This work was carried out in the support of projects of ,Student Grant Competition" numbers SP2021/39 a SP2021/41. The article was created thanks to the project No.

CZ.02.1.01/0.0/0.0/17_049/0008399 from the EU and CR financial funds provided by the Operational

Programme Research, Development and Education, Call 02_17_049 Long-Term Intersectoral Cooperation for ITI, Managing Authority: Czech Republic - Ministry of Education, Youth and Sports. The work was also created with the support of the project CZ.02.2.69/0.0/0.0/16_018/0002706 FMT VŠB-TUO - Strategic Development of Doctoral Study Programs. 


\section{REFERENCES}

[1] ADOLF, Z. Teorie procesů při výrobě železa a oceli Část II - Teorie ocelářských pochodů. first edition. VSB Technical University of Ostrava, 2013, p. 94. ISBN 978-80-248-3349-1.

[2] KEPKA, M. Rafinace oceli. first edition. Praha: SNTL, 1989, p. 200. ISBN 80-03-00079-31989.

[3] MICHALEK, K.; SOCHA, L.; ADOLF, Z.; BAŽAN, J. Rafinace a odlévání oceli: didactic text. VSB - Technical University of Ostrava, 2013, p. 89. ISBN 978-80-248-3551-4.

[4] MICHALEK, K.; GRYC, K. Čistota a užitné vlastnosti oceli: studijní opora: didactic text. VSB - Technical University of Ostrava, 2010, p. 316.

[5] POSCH, W., PRESLINGER, H., MAYR, M., KLEPP, K, O., HUEBLER, H. Steel Desulphurisation and Sulphur Bonding in Solidified Ladle Slags. Steel research international [online]. Weinheim: Wiley-VCH GmbH. 2003, vol. 74, no. 2, p. 91-98. Available from: <https://doi.org/10.1002/srin.200300166>.ISSN 0177-4832.

[6] SNIEGOŇ, M. Analýza pánvových strusek s využitím SW FactSage. Ostrava, 2020. Diploma Thesis (Ing.). VSB Technical University of Ostrava, Faculty of materials science and technology, Department of Metallurgy and Foundry.

[7] BALE, CW., BÉliSLE, E., CHARTRAND, P., DECTEROV, S. A.; ERIKSSON, G., HACK, K., JUNG, I. Ho., KANG, Y. B., MELANÇON, J., PELTON, A, D., ROBELIN, CH., PETERSEN, S. FactSage Thermochemical Software and Databases - Recent Developments. Part of special issue: Tools for Computational Thermodynamics [online]. Amsterdam: Elsevier. 2009, vol. 33, no. 2, pp. 295-311. Available from: $<$ https://doi.org/10.1016/i.calphad.2008.09.009>. ISSN 0364-5916

[8] LACHMUND, H., YONGKUN, X.; HARSTE, K. Thermodynamic and kinetic aspects of the desulphurisation reaction in secondary metalurgy. Steel research international [online]. Weinheim: Wiley-VCH GmbH. 2001, vol.72, no.11-12, pp. 452-459. Available from: < https://doi.org/10.1002/srin.200100151>. ISSN 1869-344X

[9] TAKASHI, D., KAMO, M., KUROSE, Y., NOMURA, H. Deep steel desulphurisation technology in ladle furnace at KSC. In: 6th International Conference on Clean Steel: IRONMAKING \& STEELMAKING [online]. London: Taylor \& Francis. 2003, vol. 30, no. 2, p. 116-119. Available from: <https://doi.org/10.1179/030192303225001711>. ISSN 0301-9233

[10] PISTORIUS, P, CH., DEBDUTTA, R., NEERAV, V. Examples of How Fundamental Knowledge can Improve Steelmaking: Desulphurisation Kinetics Calcium and Modification. Transactions of the indian institute of Metals [online]. Berlin, Heidelberg: Springer. 2013, vol. 66, no. 5-6, pp. 519-523. Available from: <https://doi.org/10.1007/s12666-013-0303-5>. ISSN 0972-2815

[11] BING, L., BIAO, T., ZHEN, M., HANCHI, CH., HONGBO, L. Physical and Chemical Properties of Steel Slag and Utilization Technology of Stee/ Slag at Home and Abroad. In: IOP Conference Series: Earth and Environmental Science [online]. Bristlo: IOP Publishing, 2019, vol. 242, no. 3, pp. 1-5. Available from: <https://iopscience.iop.org/article/10.1088/1755-1315/242/3/032012>. ISSN 1755-1315

[12] MA, W.-J., BAO, Y.-P., WANG, W., ZHAO, D. W. Influence of slag composition on bearing steel cleanness. In: IRONMAKING \& STEELMAKING [online]. London: Taylor \& Francis. 2014, vol. 41, no.1, p. 26-30. Available from: $<$ https://doi.org/10.1179/1743281212Y.0000000096>. ISSN 0301-9233

[13] CARDOSO DA ROCHA, V., CUNHA ALVES, P., ANÍBAL MORALES PEREIRA, J., PEGORARO LEAL, L., VIANA BIELEFENDTL, W., CEZAR FARIA VILELA, A. Experimental and thermodynamic analysis of MgO saturation in the $\mathrm{CaO}-\mathrm{SiO}_{2}-\mathrm{Al}_{2} \mathrm{O}_{3}-\mathrm{MgO}$ slag system melted in a laboratory resistive furnace. Journal of Materials Research and Technology [online]. Amsterdam: Elsevier. 2019, vol. 8, no. 1, pP. 861-870. Available from: $<$ https://doi.org/10.1016/j.jmrt.2018.05.022>. ISSN 2238-7854

[14] BULKO, B., KIJAC, J., BOROVSKY, T. The influence of chemical composition of steel on steel desulphurization. Archives of metallurgy and materials [online]. Kraków: Commitee on Metallurgy of Polish Academy of Sciences 2011, vol. 56, no. 3, p. 605-609. Available from: <10.2478/v10172-011-0065-1>. ISSN 1733-3490

[15] ANDERSSON, M., HALLBERG, M., JONSSON, L., JONSSON, P. Slag-metal reactions during ladle treatment with focus on desulphurization. IRONMAKING \& STEELMAKING [online]. London: Taylor \& Francis. 2002, vol. 29, no. 3, p. 224-232. Available from: <https://doi.org/10.1179/030192302225004106>. ISSN 0301-9233 
[16] YOON, BH., HEO, KH., KIM, JS., SOHN, HS. Improvement of steel cleanliness by controlling slag composition. IRONMAKING \& STEELMAKING [online]. London: Taylor \& Francis. 2002, vol. 29, no. 3, pP. 215-218. Available from: $<$ https://doi.org/10.1179/030192302225004160>. ISSN 0301-9233

[17] HUIXIANG, Y., DEXIN, Y., MUMING, L., NI, Z. Effects of Al Addition on the Reaction between High-Manganese Steel and CaO-SiO2-Al2O3-MgO Slag. Steel research international [online]. Weinheim: Wiley-VCH GmbH 2020, vol. 91, no. 10, pp. 1-6. Available from: <https://doi.org/10.1002/srin.202000143>. ISSN 1611-3683

[18] CHRIS, P, P., DEBDUTTA, R., NEERAV, V. Examples of How Fundamental Knowledge can Improve Steelmaking: Desulphurisation Kinetics Calcium and Modification. Transactions of the indian institute of metals [online]. Berlin, Heidelberg: Springer. 2013, vol. 66, no. 5-6, pp. 519-523. Available from: $<$ https://doi.org/10.1007/s12666-013-0303-5>. ISSN 0972-2815 